\title{
REDUCTION OF Np(VI) AND Pu(VI) BY ORGANIC CHELATING AGENTS
}

\author{
By D. T. Reed, D. G. Wygmans, S. B. Aase and J. E. Banaszak \\ CONF-971090 -.
}

Argonne National Laboratory, 9700 S. Cass Avenue, Argonne, Illinois 60439-4837

Plutonium / Neptunium / Waste Isolation Pilot Plant (WIPP) / Organic Chelates / Reduction

\begin{abstract}
The reduction of $\mathrm{NpO}_{2}{ }^{2+}$ and $\mathrm{PuO}_{2}{ }^{2+}$ by oxalate, citrate, and ethylenediaminetetraacetic acid (EDTA) was investigated in low ionic strength media and brines. This was done to help establish the stability of the An(VI) oxidation state in the presence of organic complexants. The stability of the An(VI) oxidation state depended on the $\mathrm{pH}$ and relative strength of the various oxidation state-specific complexes. At low ionic strength and $\mathrm{pH} 6, \mathrm{NpO}_{2}{ }^{2+}$ was rapidly reduced to form $\mathrm{NpO}_{2}{ }^{+}$organic complexes. At longer times, $\mathrm{Np}$ (IV) organic complexes were observed in the presence of citrate. $\mathrm{PuO}_{2}{ }^{2+}$ was predominantly reduced to $\mathrm{Pu}^{4+}$, resulting in the formation of organic complexes or polymeric/hydrolytic precipitates. The relative rates of reduction to the $A n(V)$ complex were EDTA $>$ citrate > oxalate. Subsequent reduction to An(IV) complexes, however, occurred in the following order: citrate $>$ EDTA $>$ oxalate because of the stability of the An(V)-EDTA complex. The presence of organic complexants led to the rapid reduction of $\mathrm{NpO}_{2}{ }^{2+}$ and $\mathrm{PuO}_{2}{ }^{2+}$ in G-Seep brine at pHs 5 and 7. At pHs 8 and 10 in ERDA- 6 brine, carbonate and hydrolytic complexes predominated and slowed down or prevented the reduction of An(VI) by the organics present.
\end{abstract} FIVES JUN 151998

\section{Introduction}

The role of organic compounds in defining actinide speciation and mobility in subsurface groundwaters is growing in importance [1-8]. Organic species are present in the subsurface from both natural (e.g. hydro-geological and microbiological activity) and anthropogenic sources $[1,2]$. In far-field studies, the long-term mobility of actinide species has been linked to their association/interaction with organic species [3]. Enhanced radionuclide migration has been associated with organic complexants [4,5], and natural organics present in the subsurface [6-8].

Organic complexants directly affect the speciation of dissolved actinides in two ways. They can form oxidation state-specific complexes that increase the solubility of the oxidation state and stabilize it to subsequent reduction or oxidation. The second, perhaps less recognized effect, is that many organic chelating agents reduce and/or oxidize the multivalent actinides. The 


\section{DISCLAIMER}

This report was prepared as an account of work sponsored by an agency of the United States Government. Neither the United States Government nor any agency thereof, nor any of their employees, makes any warranty, express or implied, or assumes any legal liability or responsibility for the accuracy, completeness, or usefulness of any information, apparatus, product, or process disclosed, or represents that its use would not infringe privately owned rights. Reference herein to any specific commercial product, process, or service by trade name, trademark, manufacturer, or otherwise does not necessarily constitute or imply its endorsement, recommendation, or favoring by the United States Government or any agency thereof. The views and opinions of authors expressed herein do not necessarily state or reflect those of the United States Government or any agency thereof. 
net effect of organic complexants on actinide speciation is therefore a combination of their indirect effect on biological activity, their complexation, and their ability to reduce or oxidize the multivalent actinides.

Herein we report the results of two studies to establish the effect of oxalic acid, citric acid, and EDTA on the stability of $\mathrm{PuO}_{2}{ }^{2+}$ and $\mathrm{NpO}_{2}{ }^{2+}$. We do not address the effects of other reducing agents expected to be present in the WIPP (e.g. iron and iron oxy-hydroxides). First, we established the oxidation state stability of $\mathrm{An}(\mathrm{VI})$ in low ionic strength media, at $\mathrm{pH} \sim 6$, in the presence of oxalic acid, citric acid, or EDTA. Second, we investigated the oxidation state stability in simulated WIPP brines as a function of $\mathrm{pH}$, brine composition, and carbonate concentration in the presence of a mixture of citrate, oxalate, and EDTA. The results obtained help establish the effects of organic waste constituents on actinide speciation and solubility in the proposed. Waste Isolation Pilot Plant (WIPP) repository.

\section{Experimental}

The isotopic purity of the ${ }^{242} \mathrm{Pu}$ used was $>99 \%$ by mass and $50 \%$ by curie content. The isotopic impurity in this sample was ${ }^{238} \mathrm{Pu}$. The ${ }^{237} \mathrm{~Np}$ used was $>99 \%$ pure by mass and $\sim 97 \%$ pure by curie content. Both plutonium and neptunium were oxidized to the An(VI) oxidation state by fuming in perchloric acid and evaporating to near-dryness. They were dissolved in highpurity water ( $>18 \mathrm{M}$-ohm Bamstead Nanopure), checked spectroscopically for oxidation-state purity, and used to prepare the actinide solutions for both the low ionic strength and brine solutions. Citric acid (Aldrich $99.5+\%$ purity ACS reagent grade), oxalic acid (Aldrich $99+\%$ reagent grade) and EDTA (Aldrich 99+\% reagent grade) were used for the low-ionic-strength experiments. The monosodium salt of citric acid (Aldrich $99+\%$ reagent grade), oxalic acid, and the disodium salt dihydrate EDTA (Aldrich $99+\%$ reagent grade) were used in the brine experiments. All organic reagents were used without further purification. 
The low-ionic-strength experiments were conducted at room temperature $\left(21 \pm 2{ }^{\circ} \mathrm{C}\right)$ in high purity water, in the dark, and with an excess of the organic chelating agent of interest. Four experiments were conducted for $10^{-4} \mathrm{M}$ solutions of each actinide in the following systems: (1) high-purity water (i.e., no organic species), (2) $4.93 \times 10^{-3} \mathrm{M}$ Citrate, (3) $5.07 \times 10^{-3} \mathrm{M}$ oxalate, and 4) $4.98 \times 10^{-4} \mathrm{M}$ EDTA. The $\mathrm{pH}$ was adjusted to 6 using either sodium hydroxide or hydrochloric acid and was buffered by the organic species present. The actinide oxidation state was monitored as a function of time by absorption spectrometry (CARY-5 spectrometer, see Table 1 for absorption maxima). Actinide concentrations were determined using alpha scintillation counting. The duration of the experiments was 197 days for the neptunium experiments and 110 days for the plutonium experiments performed.

Analogous experiments were done in simulated WIPP brine (see Table 2). Two brines, ERDA- 6 at pH 8 and 10 and G-Seep at pH 5 and 7, were investigated. These experiments were performed in a controlled-temperature nitrogen glovebox at $25 \pm 2{ }^{\circ} \mathrm{C}$, under anoxic conditions, and in the dark. In these experiments a mixture of oxalic acid, citric acid and EDTA was added. The organic acid concentrations were $2.0 \times 10^{-4} \mathrm{M}, 2.0 \times 10^{-4} \mathrm{M}$ and $2.4 \times 10^{-4} \mathrm{M}$ for EDTA, oxalate and citrate respectively. Carbonate, when required, was added to the brine experiments as an actinide-carbonate complex. No change in $\mathrm{pH}$ was noted as a result of the addition of the actinide to the brine solution. The duration of these experiments was two months.

\section{Results and Discussion}

\section{Reduction of $\mathrm{PuO}_{2}{ }^{2+}$ by Organic Complexants in Low Ionic Strength Media}

The extent of $\mathrm{PuO}_{2}{ }^{2+}$ reduction, as a function of time and organic complexant, is shown in Figure 1. Plutonium (VI) was reduced in all of the systems studied. In high purity water, a slow reduction to $\mathrm{Pu}(\mathrm{V})$ was noted and attributed to radiolytic effects. Approximately $60 \%$ of 
the $\mathrm{PuO}_{2}{ }^{2+}$ initially present was reduced to $\mathrm{PuO}_{2}{ }^{+}$after 110 days. No evidence of further reduction to $\mathrm{Pu}(\mathrm{IV})$ species was noted.

At pH 6, all three organic complexants reduced $\mathrm{PuO}_{2}{ }^{2+}$. Oxalate formed a $\mathrm{Pu}(\mathrm{VI})-$ oxalate complex $\left(\lambda_{\max }\right.$ at $\left.845.5 \mathrm{~nm}\right)$ that was slowly reduced by the oxalate present. For the concentrations investigated, approximately $50 \%$ of the $\mathrm{Pu}(\mathrm{VI})$-oxalate complex was reduced after 500 h. This increased to $\sim 83 \%$ after 110 days. The reduction of the $\mathrm{Pu}(\mathrm{VD})$-oxalate complex did not lead to the buildup of a $\mathrm{Pu}(\mathrm{V})$-oxalate complex. Instead, plutonium polymers were formed that resulted in a net decrease in plutonium concentration in the system.

Citrate formed a $\mathrm{Pu}(\mathrm{VI})$-citrate complex $\left(\lambda_{\max }\right.$ at $\left.856.2 \mathrm{~nm}\right)$ that was more rapidly reduced by citrate. Approximately $50 \%$ of the $\mathrm{PuO}_{2}{ }^{2+}$ initially present in solution was reduced after 100 hours. After 110 days, approximately $5 \%$ of the $\mathrm{Pu}(\mathrm{VI})$ was still left in solution. The reduction of the $\mathrm{Pu}(\mathrm{VI})$-citrate complex led to the formation of $\mathrm{Pu}(\mathrm{V})$-citrate $\left(\lambda_{\max }\right.$ at $\left.549 \mathrm{~nm}\right)$ and $\mathrm{Pu}(\mathrm{IV})$-citrate (absorption bands at $689,657,506$, and $497.5 \mathrm{~nm}$ ) complexes. After 110 days, the $\mathrm{Pu}(\mathrm{IV})$-citrate complex was predominant.

The reduction of $\mathrm{PuO}_{2}{ }^{2+}$ in the presence of EDTA was instantaneous. For this reason, no spectral data on the Pu(VI) EDTA complex could be obtained. Initially, the predominant product was the $\mathrm{Pu}(\mathrm{V})$-EDTA complex $\left(\lambda_{\max }\right.$ at $\left.545 \mathrm{~nm}\right)$. This complex was reduced further to form a Pu(IV)-EDTA complex (absorption bands at 655, 686 and $504 \mathrm{~nm}$ ). Although the rate of reduction to $\mathrm{Pu}(\mathrm{V})$ was much more rapid than observed for citrate, net reduction to $\mathrm{Pu}(\mathrm{IV})$ species was significantly slower.

The relative rates for reducing $\mathrm{Pu}(\mathrm{VI})$ to $\mathrm{Pu}(\mathrm{V})$ species were as follows: EDTA $>$ citrate $>$ oxalate. This is consistent with established trends for the reduction of plutonium by amines, carboxylic acids, and tertiary alcohols. The relative rates for reducing $\mathrm{Pu}(\mathrm{VI})$ to $\mathrm{Pu}(\mathrm{IV})$ were: citrate $>$ EDTA $>$ oxalate. These results simply reflect the importance of complexation on stabilizing the $\mathrm{Pu}(\mathrm{V})$ oxidation state against further reduction to $\mathrm{Pu}(\mathrm{IV})$ species. Oxalic acid, 
which forms a weak $\mathrm{Pu}(\mathrm{V})$ and $\mathrm{Pu}(\mathrm{IV})$ complex, did not stabilize $\mathrm{Pu}(\mathrm{V})$ or prevent polymer formation at $\mathrm{pH} 6$.

\section{Reduction of $\mathrm{PuO}_{2}^{2+}$ by Organic Complexants in Simulated Brines}

The stability of $\mathrm{PuO}_{2}{ }^{2+}$ in selected WIPP brines (see Table 3) was evaluated by placing a mixture of EDTA, citrate and oxalate in the following simulated WIPP brines: ERDA- 6 at $\mathrm{pH} 8$ and 10 with carbonate, ERDA-6 at pH 10 without carbonate, and G-Seep at $\mathrm{pH} 5$ and 7 . Spectra and trends obtained were compared to the results obtained in the low ionic strength experiments to identify the oxidation state and/or complex present and establish effects specific to the brine system investigated. The final absorption spectra obtained in each brine are shown in Figure 2.

In G-Seep brine, at both pH 5 and 7, the same result was obtained. The $\mathrm{Pu}(\mathrm{VI})$ aquo/chloride species, which we have shown to be stable for more than 18 months [9], was rapidly reduced to form $\mathrm{Pu}(\mathrm{V})$ and $\mathrm{Pu}(\mathrm{IV})$ organic complexes. These complexes were relatively stable over the duration of our experiments.

In ERDA- 6 brine, the presence of carbonate slowed/prevented the reduction of Pu(VI) by the organics present. At $\mathrm{pH} 8$ (experiment Pu-ORG-E8), the initial spectrum was a $\mathrm{Pu}(\mathrm{VI})$ aquo/organic species that, over time, was reduced to form $\mathrm{Pu}(\mathrm{IV})$ and $\mathrm{Pu}(\mathrm{V})$ species that were not well correlated with spectra obtained in G-Seep brine at lower $\mathrm{pH}$. Further work is needed to establish the specific plutonium species observed in these spectra. At pH 10 when carbonate was present, the Pu(VI) -carbonate complex predominated. Little or no reduction occurred. When carbonate was not present at $\mathrm{pH} 10$, the $\mathrm{Pu}(\mathrm{VI})$ hydrolytic species $\left(\lambda_{\max }\right.$ at $\left.860 \mathrm{~nm}\right)$ was slowly

reduced. No significant buildup of $\mathrm{Pu}(\mathrm{V})$ or $\mathrm{Pu}(\mathrm{IV})$ species was noted so presumably the $\mathrm{Pu}(\mathrm{IV})$ generated was being precipitated as a Pu(IV) phase (e.g. Pu polymer or hydroxide phase).

Although there are significant differences between the brine experiments and the lowionic-strength experiments, some comparisons can be made. At near neutral pH (i.e. the lowionic-strength experiments and G-Seep brine experiments), all Pu(VI) species were reduced. In 
brine, the observed rates of reduction were most similar to those observed in the EDTA lowionic-strength experiment. This is not surprising since the EDTA in the organic mixture used is the most redox active of the three organic complexants. The Pu(IV) organic complexes are expected to predominate in this $\mathrm{pH}$ range.

At higher pHs, carbonate and hydrolytic species compete with the organic complexes and have a substantial effect on the stability of $\mathrm{Pu}(\mathrm{VI})$. In the presence of carbonate, $\mathrm{Pu}(\mathrm{VI})$ forms stable $\mathrm{Pu}(\mathrm{VI})$ carbonate complexes at $\mathrm{pH} 10$ but at $\mathrm{pH} 8$, the $\mathrm{Pu}(\mathrm{VI})$ carbonate complex is destabilized by the organics present and $\mathrm{Pu}(\mathrm{VI})$ species are reduced to form $\mathrm{Pu}(\mathrm{IV})$ and $\mathrm{Pu}(\mathrm{V})$ organic complexes. In the absence of carbonate at $\mathrm{pH} 10$, a much slower but definite reduction of $\mathrm{Pu}(\mathrm{VI})$ is noted. These data contrast with prior experiments [9], where the carbonate complex at $\mathrm{pH} 8$ and the hydrolytic species at $\mathrm{pH} 10$ were shown to be stable for over 18 months when no organic complexants were present.

\section{Reduction of $\mathrm{NpO}_{2}{ }^{2+}$ by Organic Complexants in Low Ionic Strength Media}

The neptunium(VI) oxidation state, as expected, was significantly less stable than the corresponding $\mathrm{Pu}(\mathrm{VI})$ species in the presence of the organic complexants investigated. The overall tendency was to form a relatively redox-stable $\mathrm{Np}(\mathrm{V})$ organic complex, although further reduction to form $\mathrm{Np}(\mathrm{IV})$ complexes was noted after 197 days for citrate. The buildup of $\mathrm{Np}(\mathrm{V})$ species in solution as a function of time is shown in Figure 3.

In the absence of organic complexants, complete reduction of $\mathrm{NpO}_{2}{ }^{2+}$ to $\mathrm{NpO}_{2}{ }^{+}$occurred under the conditions of our experiments. This was established by monitoring the buildup of $\mathrm{Np}(\mathrm{V})$ at $980.4 \mathrm{~nm}$. The \% conversion to $\mathrm{NpO}_{2}{ }^{+}$was $5.1,15.6$, and $24.4 \%$ after 1,16 , and 29 days, respectively. Complete reduction to $\mathrm{NpO}_{2}^{+}$was noted after 90 days. No further change in the absorption spectrum was noted after 197 days. This reduction was attributed to radiolytic effects and corresponds to a $G[N p(V)] \sim 2.9 \operatorname{molec} / 100 \mathrm{eV}$. 
In the presence of oxalate, $\mathrm{NpO}_{2}{ }^{2+}$ was rapidly reduced to form a $\mathrm{NpO}_{2}{ }^{+}$-oxalate complex (absorption maxima at 1030 and $988 \mathrm{~nm}$ ). After 1.9 hours, $72 \%$ of the $\mathrm{NpO}_{2}{ }^{2+}$ had been reduced. After 23 hours, essentially all the neptunium in solution was a $\mathrm{NpO}_{2}{ }^{+}$-oxalate complex. Once the $\mathrm{Np}(\mathrm{V})$ complex was formed, no further changes in the spectrum occurred. No spectral evidence for the formation of $\mathrm{Np}(\mathrm{IV})$ species was observed.

The reduction of $\mathrm{NpO}_{2}{ }^{2+}$ was more rapid in the presence of citrate. After $1.6 \mathrm{~h}, \sim 95 \%$ of the neptunium was reduced to form a $\mathrm{NpO}_{2}{ }^{+}$-citrate complex (absorption bands at 1004 and 982 $\mathrm{nm}$ ) with trace amounts of a $\mathrm{Np}(\mathrm{IV})$-citrate complex (absorption bands at 769 and $737 \mathrm{~nm}$ ) evident. After 16 days, all of the $\mathrm{Np}(\mathrm{VI})$ was gone, and there was a significant buildup of the $\mathrm{Np}$ (IV)-citrate complex in solution. After 197 days, approximately $1 / 3$ of the $\mathrm{Np}$ was reduced to a $\mathrm{Np}(\mathrm{IV})$-citrate complex.

The reduction of $\mathrm{NpO}_{2}{ }^{2+}$ was instantaneous in the presence of EDTA. The predominant complex formed was the $\mathrm{NpO}_{2}{ }^{+}$-EDTA complex (absorption bands at 1024 and $988 \mathrm{~nm}$ ) with no spectral evidence for reduction to $N p(I V)$-EDTA complexes, even after 197 days.

The reduction of $\mathrm{Np}(\mathrm{VI})$, as expected, was more rapid than the corresponding reduction of $\mathrm{Pu}(\mathrm{VI})$ species. However, the same order of reactivity was noted: EDTA $>$ citrate $>>$ oxalate. Net reduction to $\mathrm{Np}(\mathrm{IV})$-organic complexes was only noted in the case of citrate whereas all three organic complexants formed $\mathrm{Pu}(\mathrm{IV})$ species. This is consistent with the inherently greater stability of $\mathrm{Np}(\mathrm{V})$ compared to $\mathrm{Pu}(\mathrm{V})$. Under most conditions, $\mathrm{Np}(\mathrm{V})$ complexes will predominate in the presence of organic species.

It is not clear at this time why citrate alone led to the formation of $\mathrm{Np}(\mathrm{IV})$ species. Citrate is more susceptible to biodegradation and is more photo-active than EDTA. Although steps were taken to prevent these phenomena (filter-sterilized media were used and experiments were conducted in the dark) additional work is needed to verify/explain the results obtained and establish the reaction mechanism. 


\section{Reduction of $\mathrm{NpO}_{2}{ }^{2+}$ by Organic Complexants in Simulated Brines}

The experiments performed in simulated WIPP brine (see Table 3) were analogous to those performed with plutonium and were done with the same simulated brines, $\mathrm{pH}$, and carbonate concentrations. As observed with plutonium, the presence of organics led to the reduction of $\mathrm{Np}(\mathrm{VI})$ at a lower $\mathrm{pH}$. At a higher $\mathrm{pH}$, the $\mathrm{Np}(\mathrm{VI})$-carbonate complex was predominant. The final absorption spectrum obtained in each brine is shown in Figure 4.

In G-Seep brine, similar results were obtained at pHs 5 and 7 . After 1 day, over $96 \%$ of the $\mathrm{Np}(\mathrm{VI})$ had been reduced to an $\mathrm{Np}(\mathrm{V})$-organic complex. After 7 days, all of the neptunium in solution had been reduced to $\mathrm{Np}(\mathrm{V})$ species. There were no further changes in the spectra for remainder of the two-month experiments. In these experiments, there was no spectral evidence for the formation of $N p(I V)$ species.

The presence of carbonate complexes greatly reduced the rate of $\mathrm{NP}(\mathrm{VI})$ reduction in the presence of organics. The $\mathrm{Np}(\mathrm{VI})$-carbonate complex predominated at $\mathrm{pHs} 8$ and $\mathrm{pH} 10$ in ERDA- 6 brine. Based on changes in the absorption spectrum with time, we estimate that approximately $95 \%$ of the carbonate complex remained in solution after 1 month and over $80 \%$ was in solution after two months. The reduction of the $\mathrm{Np}(\mathrm{VI})$-carbonate complex led to the buildup of $\mathrm{Np}(\mathrm{V})$-organic complexes in solution. Some evidence for the formation of $\mathrm{Np}(\mathrm{IV})$ species was noted at both $\mathrm{pH} 8$ and $\mathrm{pH} 10$. In the absence of carbonate at $\mathrm{pH} 10, \mathrm{~Np}(\mathrm{VI})$ was rapidly removed from solution by reduction to form $\mathrm{Np}(\mathrm{V})$ and $\mathrm{Np}(\mathrm{IV})$-organic complexes and precipitates.

The results obtained in the simulated brines investigated can be compared to both the low-ionic-strength experimental results and the long-term studies we have conducted with no organic complexants present in solution [9]. At near-neutral $\mathrm{pH}$, reduction is rapid, and a stable $\mathrm{Np}(\mathrm{V})$ organic complex is formed. The observed rates of reduction in G-Seep brine are again most consistent with the results obtained in the EDTA low-ionic-strength experiments. 
Although carbonate complexes predominated, the formation of $N p(V)$ and $N p(I V)$ species was noted at higher $\mathrm{pHs}$. The observed reduction of $\mathrm{Np}(\mathrm{VI})$ is attributed to the presence of the organic complexants in solution since the $\mathrm{Np}(\mathrm{VI})$-carbonate complexes were shown to be stable when the organics were absent [9] and no $N p(I V / V)$ species were noted in these longerterm experiments. Reduction to $\mathrm{Np}(\mathrm{V})$ and $\mathrm{Np}(\mathrm{IV})$ species, along with precipitation, proceeds more rapidly when carbonate is not present to stabilize Np(VI).

\section{Conclusions and Observations}

The presence of organic chelating agents led to the destabilization of the Pu(VI) and $\mathrm{Np}(\mathrm{VI})$ oxidation states in most cases investigated. Significant differences in rates of reduction were noted for oxalate, citrate and EDTA. The actinide-organic systems investigated were not at steady-state so it was not possible to experimentally establish the long-term/final oxidation state distribution of the actinide complexes investigated. Evidence to date, however, is consistent with $\mathrm{Np}(\mathrm{V})$ and $\mathrm{Pu}(\mathrm{IV})$ being the predominant oxidation states in the presence of organics.

There were some similarities in the behavior of the three organic ligands investigated towards neptunium and plutonium. Oxalate, in both cases, led to significantly slower rates of reduction of $A n(V I)$. For neptunium, reduction to $N p(V)$ in the presence of both citrate and EDTA was rapid. The resultant $N p(V)$ speciation was, however, more complex. For plutonium, $\mathrm{Pu}(\mathrm{VI})$ was reduced more rapidly by EDTA than citrate. The stability of the $\mathrm{Pu}(\mathrm{V})$ species generated, however, was much greater with EDTA than citrate, leading to a slower reduction of the $\mathrm{Pu}(\mathrm{V})$ EDTA complex. Overall, citrate was a more effective reducing agent from the perspective of the formation of $\mathrm{Pu}(\mathrm{IV})$ and $\mathrm{Np}(\mathrm{IV})$ species.

In the brine systems investigated, $\mathrm{Pu}(\mathrm{VI})$ and $\mathrm{Np}(\mathrm{VI})$ were rapidly reduced in G-Seep brine at pHs 5 and 7. In ERDA-6 brine, carbonate complexation stabilized Pu(VI) towards reduction at $\mathrm{pH} 10$ but not at $\mathrm{pH}$. Slow reduction of $\mathrm{Pu}(\mathrm{VI})$ was noted at $\mathrm{pH} 10$ when 
carbonate was not present. For $\mathrm{Np}(\mathrm{VI})$, although the carbonate complex predominated at $\mathrm{pHs} 8$

and 10 , reduction by the organic complexants present to form $N p(I V)$ and $N p(V)$ species was

observed. Reduction was more rapid when no carbonate was present in solution. These data

combine to show, with the one exception of the $\mathrm{Pu}(\mathrm{VI})$ carbonate system at $\mathrm{pH} 10$, that the

presence of organic complexants promote the reduction of $\mathrm{Pu}(\mathrm{VI})$ and $\mathrm{Np}(\mathrm{VI})$ in brine systems.

\section{Acknowledgement}

The authors wish to acknowledge the help and support of Dr. Robert Moore (Sandia) who is the technical contact for this work. This work was performed under U.S. Department of Energy contract W-31-109-ENG-38 at Argonne National Laboratory as part of the Actinide Source Term Program managed by Sandia in support of the Waste Isolation Pilot Plant. Sandia is a multi-program laboratory operated by Sandia Corporation, a Lockheed Martin Company, for the United States Department of Energy under Contract DE-ACO4-94AL85000.

\section{References}

1. Riley, R.G., and , J. M. Zachara (1992). Chemical Contaminants on DOE Lands and Selection of Contaminant Mixtures for Subsurface Science Research. DOE/ER-0574T. U.S. Department of Energy, Office of Health and Environmental Research, Washington, D.C.

2. Banaszak, J. E., B. E. Rittmann and D. T. Reed, "Subsurface Interactions of Actinide Species and Microorganisms: Implications for the Bioremediation of Actinide-Organic Mixtures," accepted by the Journal of Radioanalytical and Nuclear Chemistry for publication.

3. Nelson, D. M., K. A. and W. R. Penrose (1989). "Oxidation States of Plutonium in CarbonateRich Natural Waters", J. of Environmental Radioactivity, 9(3): 189-198.

4. Baik, M.H. and K. J. Lee (1994). "Transport of Radioactive Solutes in the Presence of Chelating Agents", Annals of Nuclear Energy 21(2): 81-96.

5. Dozol, M. and R. Hagemann (1993). "Radionuclide Migration in Groundwaters; Review of the Behavior of Actinides.: Pure and Applied Chemistry 65(5): 1081-1102.

6. Choppin, G. R., (1992). "The Role of Natural Organics in Radionuclide Migration in Natural Aquifer Systems." Radiochimica Acta 58/59: 113-120.

7. Lierse, K. H. (1995). "Radionuclides in the Geosphere: Sources, Mobility, Reactions in Natural Waters and Interactions with Solids." Radiochimica Acta 70/71: 355-375.

8. Silva, R. J. and H. Nitsche (1995). "Actinide Environmental Chemistry." Radiochimica Acta 70/71: $377-396$.

9. Reed, D. T., R. C. Moore, and S. Aase, "Stability/Solubility of $\mathrm{UO}_{2}{ }^{2+}, \mathrm{NpO}_{2}{ }^{2+}$, and $\mathrm{PuO}_{2}{ }^{2+}$ in Simulated WIPP Brine" in preparation. 
Table 1. Oxidation-State Specific Absorption Maxima at $\mathrm{pH} 6$ for Plutonium and Neptunium in the Presence of Organic Chelating Agents

\begin{tabular}{|c|c|c|c|}
\hline Actinide & Complexant/Species & $\begin{array}{l}\text { Oxidation } \\
\text { State }\end{array}$ & $\begin{array}{l}\text { Absorption Maxima } \\
(\mathrm{nm})\end{array}$ \\
\hline \multirow{10}{*}{ Plutonium } & \multirow[t]{2}{*}{ Aquo/Chloride } & VI & $\begin{array}{l}830.8,839.5, \text { and } 851 \\
\text { depending on } \mathrm{pH}\end{array}$ \\
\hline & & $\mathrm{V}$ & 569 \\
\hline & Oxalate & VI & 845.5 \\
\hline & \multirow[t]{3}{*}{ Citrate } & VI & 856.2 \\
\hline & & $\mathrm{V}$ & 549 and 569 \\
\hline & & IV & $689,657,506$, and 497.5 \\
\hline & \multirow[t]{2}{*}{ EDTA } & $\mathrm{V}$ & 545 \\
\hline & & IV & 655,686 , and 504 \\
\hline & \multirow[t]{2}{*}{ Aquo/Chloride } & $\mathrm{VI}$ & 1223 \\
\hline & & $\mathrm{V}$ & 980.4 \\
\hline \multirow[t]{4}{*}{ Neptunium } & Oxalate & $\mathrm{V}$ & $1030,988,480$, and 445 \\
\hline & \multirow[t]{2}{*}{ Citrate } & $\mathrm{V}$ & 1004 and 982 \\
\hline & & IV & 769,737 , and 618 \\
\hline & EDTA & $\mathrm{V}$ & 1024,988 , and 617 \\
\hline
\end{tabular}

Table 2. Composition of the G-Seep and ERDA-6 Simulated WIPP Brines

\begin{tabular}{|c|c|c|}
\hline $\begin{array}{l}\text { Element or } \\
\text { Species }\end{array}$ & $\begin{array}{c}\mathrm{ERDA}^{\mathrm{a}} 6^{\mathrm{a}} \\
(\mathrm{M})\end{array}$ & $\begin{array}{l}\text { G-Seep } \\
(M)\end{array}$ \\
\hline $\mathrm{Cl}$ & 4.18 & 4.56 \\
\hline $\mathrm{SO}_{4}^{-2}$ & 0.150 & 0.267 \\
\hline $\mathrm{B}$ & 0.057 & 0.13 \\
\hline${ }^{\circ} \mathrm{CO}_{3}{ }^{2-} / \mathrm{HCO}_{3}{ }^{-}$ & 0 & 0 \\
\hline $\mathrm{Br}$ & 0.010 & 0.015 \\
\hline $\mathrm{Na}$ & 4.37 & 3.76 \\
\hline $\bar{K}$ & 0.087 & 0.304 \\
\hline $\mathrm{Mg}$ & 0.017 & 0.551 \\
\hline $\mathrm{Ca}$ & 0.011 & 0.0069 \\
\hline \multicolumn{3}{|c|}{$\begin{array}{l}{ }^{\mathrm{a}} \text { This is a Castile synthetic brine at pHs } 8 \text { and } 10 \text {. } \\
{ }^{\mathrm{b}} \text { This is a Salado synthetic brine at pHs } 5 \text { and } 7 .\end{array}$} \\
\hline \multicolumn{3}{|c|}{$\begin{array}{l}\text { 'Carbonate was added with the actinide to a concentration of } 2 \\
\mathrm{mM}\end{array}$} \\
\hline
\end{tabular}


Table 3. Experimental Matrix to Determine the Redox Stability of Pu(VI) and $\mathrm{Np}(\mathrm{VI})$ in the Presence of Chelating Agents

\begin{tabular}{|c|c|c|}
\hline Actinide & $\begin{array}{l}\text { Experiment } \\
\text { Designation }\end{array}$ & $*$ Brine and $\mathrm{pH}$ \\
\hline \multirow[t]{5}{*}{$\mathrm{Pu}-242$} & PU-ORG-E8 & Organics in ERDA-6 with $10^{-4} \mathrm{M}$ Carbonate at $\mathrm{pH} 8$ \\
\hline & PU-ORG-E10 & Organics in ERDA-6 with $10^{-4} \mathrm{M}$ Carbonate at $\mathrm{pH} 10$ \\
\hline & PU-ORG-E10-NC & Organics in ERDA- 6 at $\mathrm{pH} 10$, no carbonate \\
\hline & PU-ORG-G5 & Organics in G-Seep at pH 5 \\
\hline & PU-ORG-G7 & Organics in G-Seep at pH 7 \\
\hline \multirow{5}{*}{ Np-237 } & NP-ORG-E8 & Organics in ERDA-6 with $10^{-4} \mathrm{M}$ Carbonate at $\mathrm{pH} 8$ \\
\hline & NP-ORG-E10 & Organics in ERDA-6 with $10^{-4} \mathrm{M}$ Carbonate at $\mathrm{pH} 10$ \\
\hline & NP-ORG-E10-NC & Organics in ERDA- 6 at $\mathrm{pH} 10$, no carbonate \\
\hline & NP-ORG-G5 & Organics in G-Seep at pH 5 \\
\hline & NP-ORG-G7 & Organics in G-Seep at $\mathrm{pH} 7$ \\
\hline \multirow{4}{*}{$\begin{array}{l}\text { Actinide } \\
\text { Blanks }\end{array}$} & B-ORG-G5 & Organics in G-Seep at pH 5 \\
\hline & B-ORG-G7 & Organics in G-Seep at $\mathrm{pH} 7$ \\
\hline & B-ORG-E8 & Organics in ERDA-6 at $\mathrm{pH} 8$ \\
\hline & B-ORG-E10 & Organics in ERDA-6 at $\mathrm{pH} 10$ \\
\hline & nt contained 2 & $\begin{array}{l}\mathrm{mM} \text { of EDTA, citrate and oxalate with } 0.1 \mathrm{mM} \text { of the } \\
\text { actinide }\end{array}$ \\
\hline
\end{tabular}




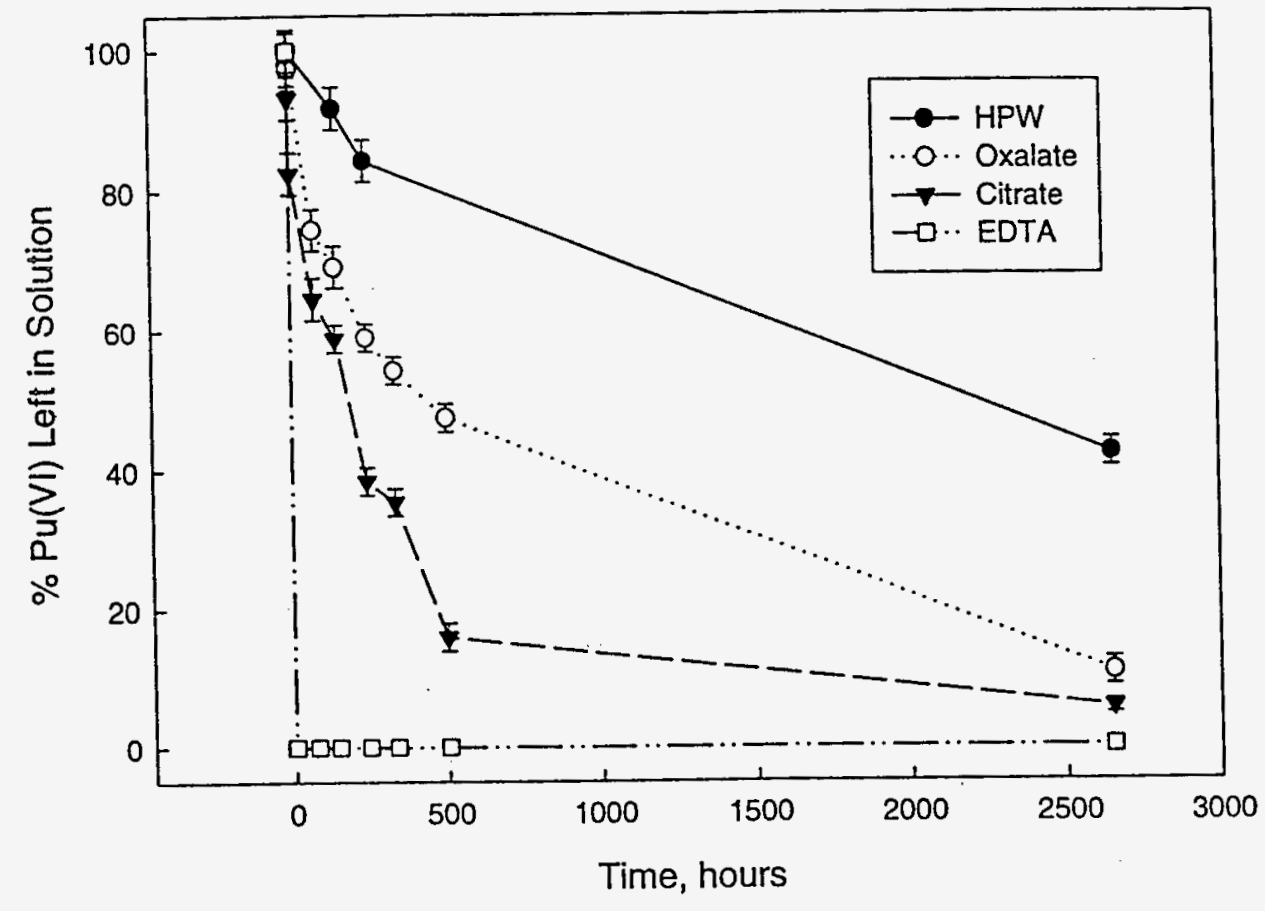

Figure 1. Reduction of Pu(VI) in the Low Ionic Strength Organic Interaction Studies as a Function of the Organic Complexant Present. 

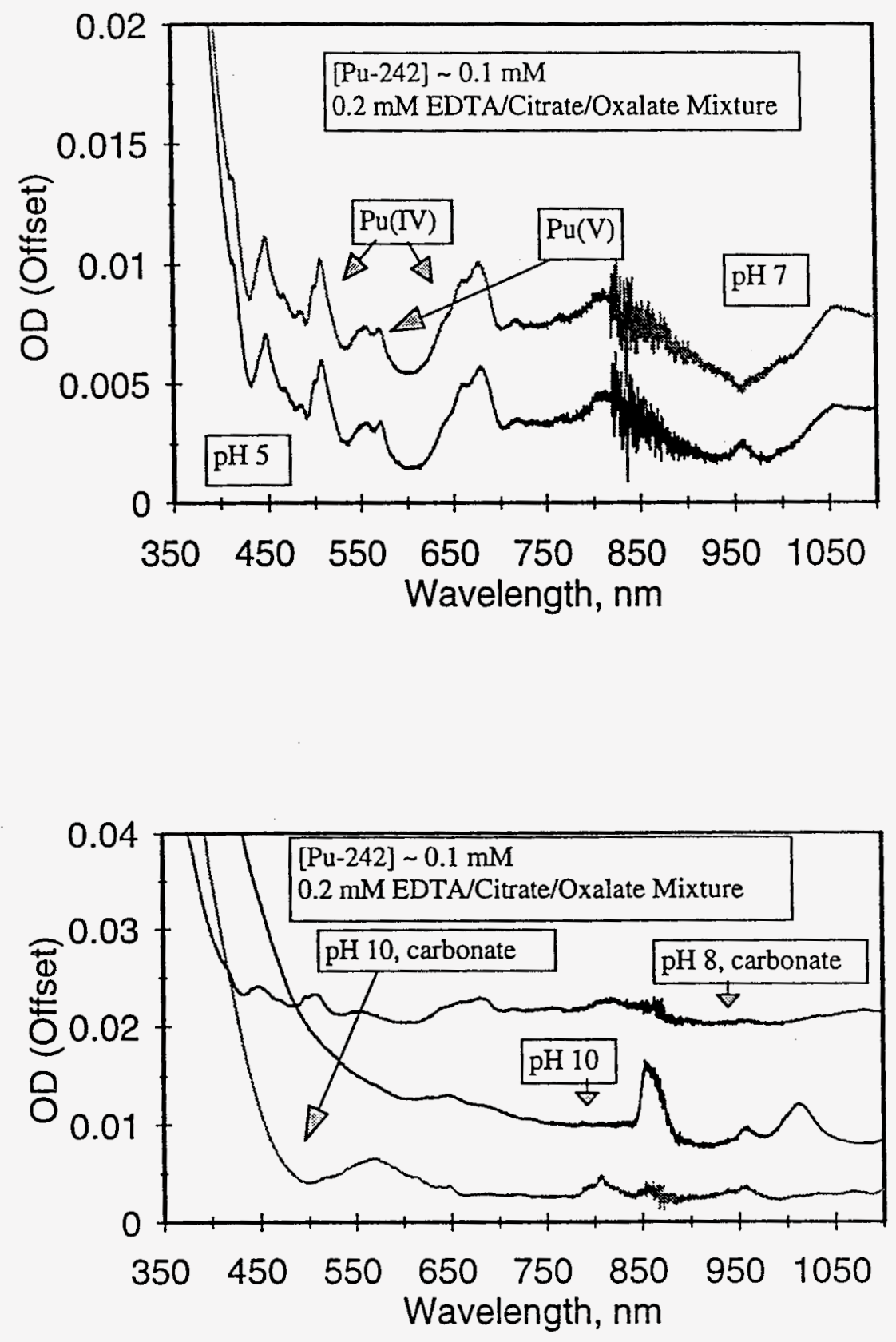

Figure 2. Final Absorption Spectra for Plutonium in the Simulated Brine Experiments for G-Seep Brine (Top) and ERDA-6 Brine (Bottom). 


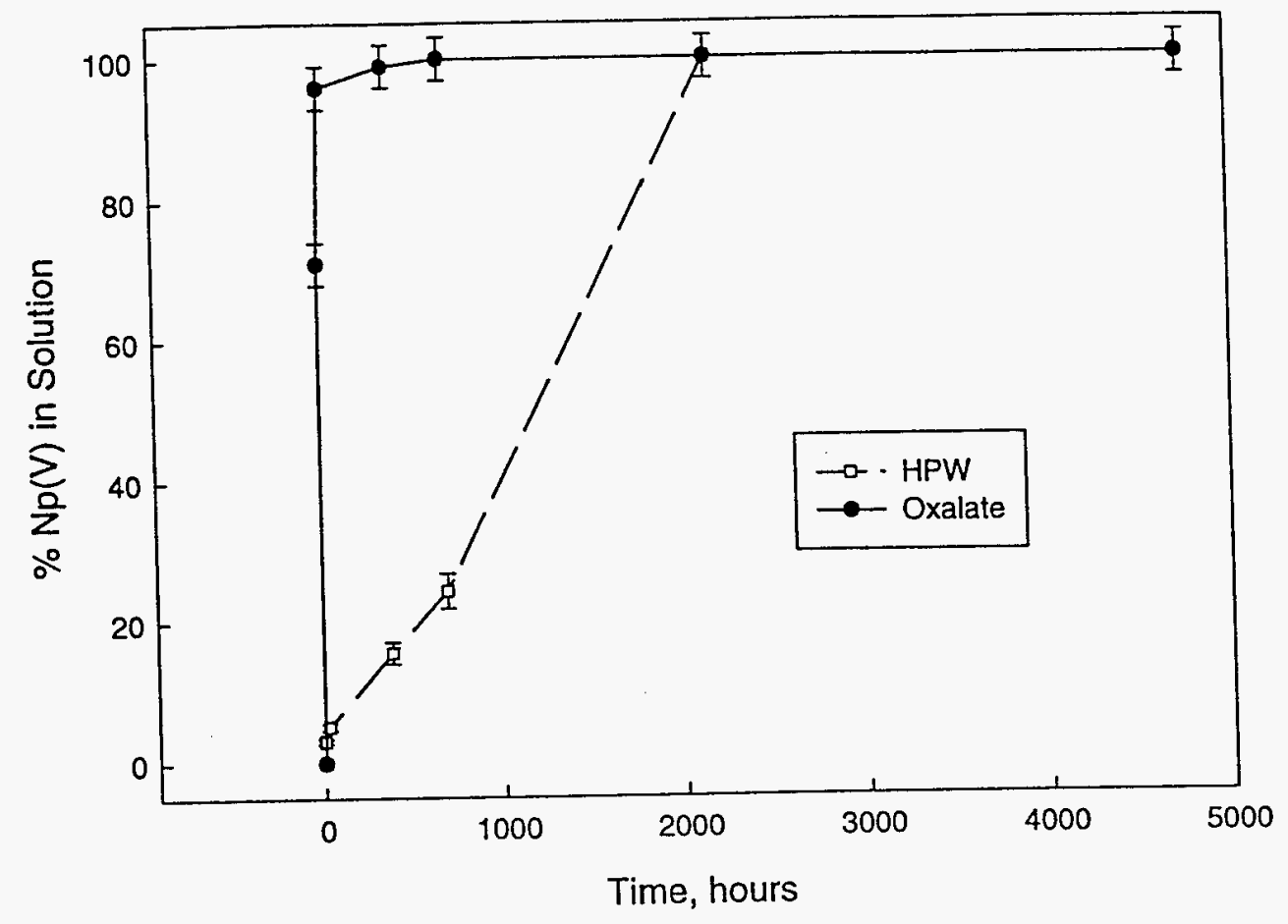

Figure 3. Buildup of $\mathrm{Np}(\mathrm{V})$ as a Function of Time due to Reduction in the Low Ionic Strength Organic Experiments. Reduction for Citrate and EDTA (not shown) was Instantaneous on the Time-Scale Above. 

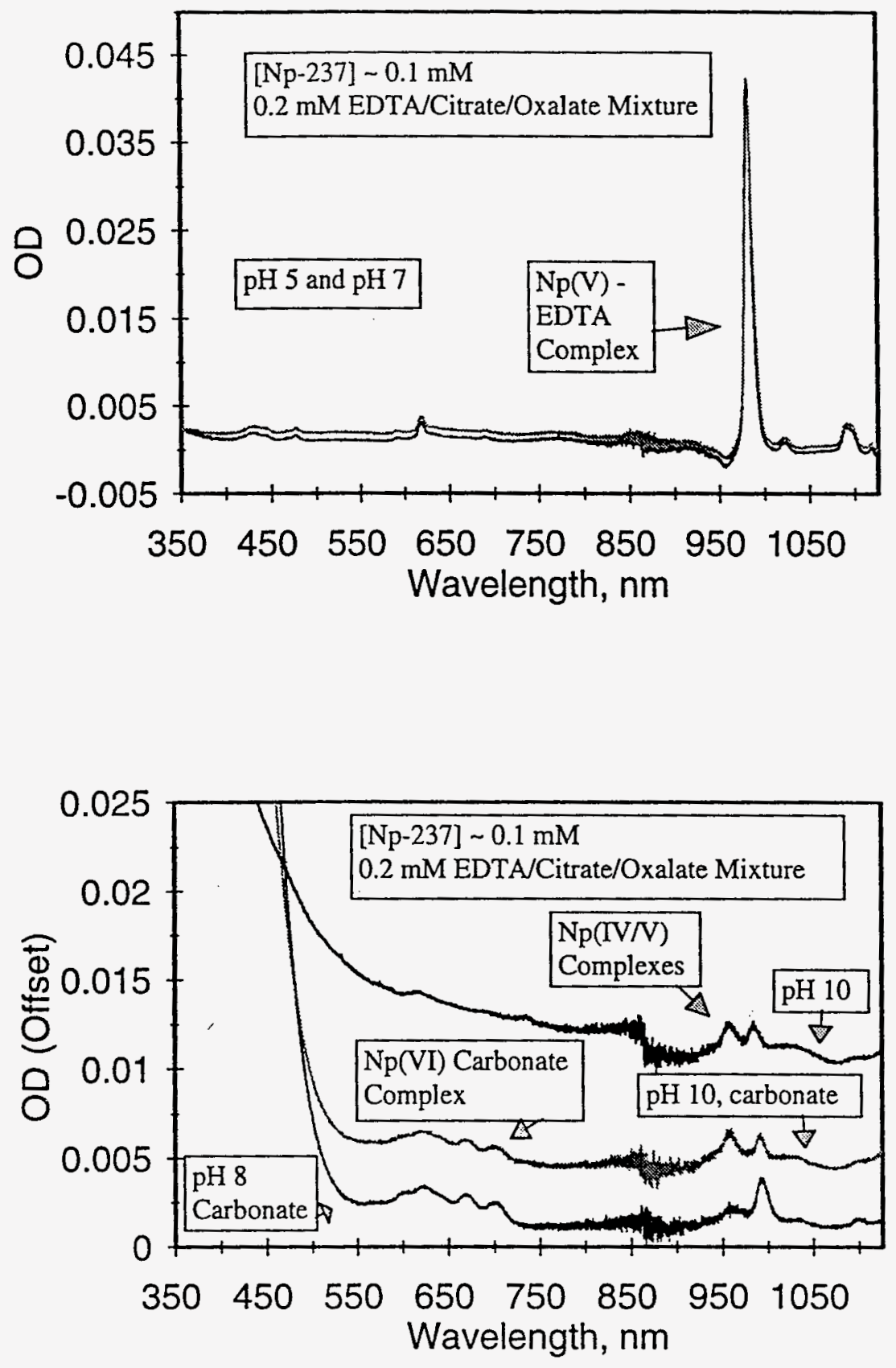

Figure 4. Final Absorption Spectra for Neptunium in the Simulated Brine Experiments for G-Seep Brine (Top) and ERDA-6 Brine (Bottom). 


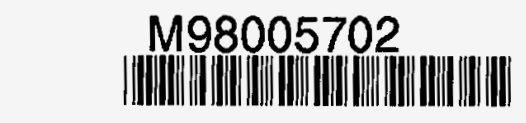

$\begin{array}{r}\text { Report Number (14) SAND }-97-2845 \mathrm{C} \\ \text { CONF }-971090-- \\ \hline\end{array}$

Publ. Date (11) 199806

Sponsor Code (18) DOE/EM , XF

UC Category (19) UC-2000, DOE/ER

19980707037

TMT QDALTTY TNOPECTED 1

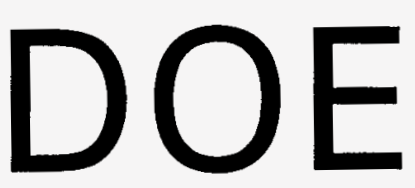

